\title{
ЉИЉАНА ЂУКАНОВИЋ
}

\section{РАЗВОЈ ТЕХНИКА ГРАЪЕЊА У СТАМБЕНОЈ АРХИТЕКТУРИ БЕОГРАДА ТОКОМ 19. И ПОЧЕТКОМ 20. ВЕКА}

\begin{abstract}
САЖЕТАК:
Промене које су се догодиле током 19. века на политичком, економском и друштвеном плану утицале су да Београд доживи потпуни преображај и од полуразрушене турске вароши прерасте у модеран европски град. Ослобађање од турске власти и стабилизација политичких и економских прилика допринели су порасту броја становника у граду и интензивирању градитељске делатности. Београд, по узору на друге европске престонице, доживљава архитектонски и урбанистички преображај и постепено губи дотадашња обележја оријенталне вароши. Прихватање нових техника грађења током 19. века представљало је начин да се домаћи системи грађења усагласе с масивним зиданим системом у грађењу кућа који су већ усвојиле технички развијеније средњоевропске земље. У раду је истражен процес преласка са оријенталног начина грађења, где је бондрук био неприкосновени систем, на зидани масивни склоп са опеком као основним материјалом конструкције.
\end{abstract}

Рад је део ширег и временски обухватнијег истраживања техника грађења у стамбеној архитектури Београда, рађеног за потребе дефинисања типологије склопова елемената конструкције с циљем да се валоризује квалитет стамбеног комфора београдских зграда.

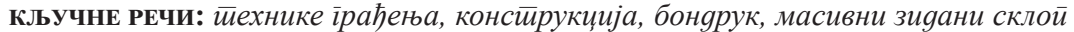

\section{ABSTRACT:}

Due to the radical political, economic and social changes of the 19th century Belgrade saw a complete transformation from a ruined Ottoman town into a modern European one. Liberation from Turkish rule and stabilisation of political and economic conditions influenced the population growth and intensified building activity. Like other European capitals, Belgrade was being transformed architecturally and in its urban plan, gradually losing traits of an Oriental town. The adoption of new building techniques in the 19th century was a way for local civil engineering to harmonise with engineering practices of the developed Central European countries which had by then already adopted masonry structure. The article studies the transition in building forms from Oriental ones, largely charatcterised by timber-framed systems, to a brick-based construction system.

This paper is part of a wider, more comprehensive research on building techniques in Belgrade's residential architecture, undertaken to define the typology of construction systems, in order to evaluate the quality of residential comfort in the buildings of Belgrade.

KEYWORDS: building techniques, construction, timber-framed system, masonry structure

$\Pi$ очетак формирања стамбеног фонда Београда поклапа се с периодом ослобађања од турске власти и успостављањем националног идентитета, процесом интензивне модернизације и урбанизације земље. То је уједно и време великих политичких превирања и промена државног уређења, о чему довољно говоре чињенице да је Србија у периоду од сто година (од победе у Другом српском устанку до Првог светског рата) променила устројство од вазалне кнежевине, преко независне кнежевине до краљевине. ${ }^{1}$ Обележје периода по коначном ослобађању од турске власти, од друге половине 19. века, биле су велике миграције у градове, што је допринело да се за кратко време становништво у Београду увећа неколико пута. ${ }^{2}$ Потреба за стамбеним простором условила је велики обим стамбене изградње, постепено прихватање савремених европских технологија градње и формирање домаће индустрије грађевинских материјала.

Кључни тренутак у развоју града било је добијање Хатишерифа 1830. године, стицање извесне самосталности и раскид с дотадашњим начином живота, препуним неизвесности, кад је свако улагање у грађевине било ризична делатност. Описујући како је изгледала београдска варош по ослобађању од Турака, Михаило С. Петровић наводи да су све зграде у вароши, изузев цркве, неких џамија и неколико других зграда, биле изграђене од сла- 

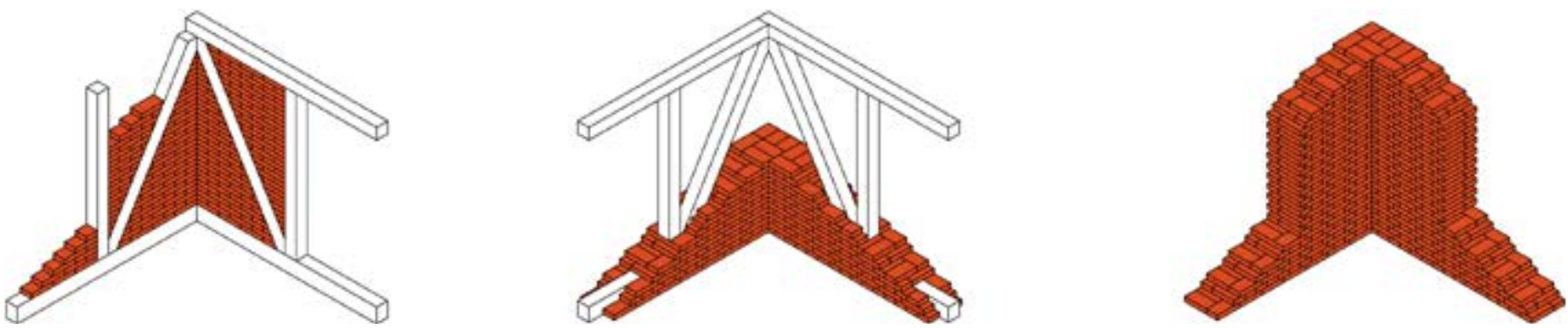

Сл. 1 / Развој консиирукииивних сисиема ірађења ииоком ирве йоловине 19. века (ириееж ауйора)

бог материјала, у бондручном систему, или као плетаре. Испуна бондрука најчешће је пола цигле ${ }^{3}$, ретко када цела, и облепљиване су блатом или малтером, а затим кречене. Већина кућа покривена је црепом, али тако лоше да - и поред сталног препокривања - прокишњавају чим падне јача киша. Прозори нису застакљивани, већ је у оквире стављана хартија иенцерлија. ${ }^{4}$

Ферманом из 1867. године и коначним исељењем војне турске власти из српских тврђава започиње просперитет Београда и појачава се градитељска делатност. Према статистичким подацима, у овом периоду долази до смањења броја кућа, што показује да се град по исељењу Турака полако урбанизовао и да су нестајали уски сокаци, брвнаре и чатрље облепљене блатом, које су до тада преовлађивале у турском делу вароши. ${ }^{5}$

Крајем 19. и почетком 20. века, долази до значајних квалитативних промена у развитку града: увођење градског водовода (1892) и канализације (1905-1914), изградња електричне централе (1892), увођење електричног осветљења (1893) и трамвајског саобраћаја, калдрмисање улица и уређење зелених површина. Изградња инфраструктуре била је предуслов за преображај престонице у савремен европски град и промене које су наступиле представљале су велики подстицај за стамбену изградњу.

Послови пројектовања и изградње више нису дело приучене, нешколоване радне снаге, већ школованих градитеља: инжењера, архитеката и мајстора, који су своја знања стицали у развијеним европским градовима.

\section{Развој конструктивних система и техника грађења у првој половини 19. века}

Промене на политичкој сцени Србије почетком 19. века покренуле су грађевинску делатност, али су нови конструктивни системи и технике грађења, познати европским градитељима, усвајани и примењивани постепено, у неколико етапа. Развојни пут од балканске бондручаре до градске куће по европским узорима од- сликава тадашње грађевинске прилике, лошу техничку опремљеност и непознавање нових техника грађења. Историчар Бранко Вујовић издваја три етапе у развоју градске куће и њеном преображају од куће оријенталног типа до куће грађене по европским принципима: ${ }^{6}$

- почетни период: 1815-1825, традиционална, балканска оријентална архитектура;

- прелазни период: 1825-1833, поступно напуштање градитељске традиције и примена нових архитектонских решења;

- завршни период: 1833-1839, усвајање западноевропског система грађења.

Оваква периодизација произашла је из промена историјских, друштвених и културних прилика, које су се нужно одсликавале и на промене на пољу градитељства.

Први период обухвата време после Другог српског устанка, стицања делимичне независности и постепеног јачања Милошеве власти. Прелазни период настаје међународним признањем Србије, добијањем националне независности и устоличавањем Милоша као врховног кнеза. Трећи период започиње добијањем хатишерифа који Србији обезбеђује аутономију а Милошу наследно кнежевско право и завршава се његовом абдикацијом и напуштањем земље.

Развој конструктивних система и техника грађења у првој половини 19. века имао је еволутивни карактер и може се на сличан начин поделити на три етапе:

- почетни период, грађење по традиционалним принципима, примена бондручне конструкције са испуном од опеке, ћерпича или плетера;

- прелазни период, преплитање традиционалних и савремених техника грађења, мешавина масивне зидане конструкције печеном циглом и бондручне конструкције;

- завршни период, усвајање масивне зидане конструкције по узору на савремене европске грађевине (сл. 1). 
Временске одреднице појединих етапа само се условно поклапају с поделом историчара Вујовића, зато што су се традиционалне технике грађења примењивале и током друге половине 19. века, кад је зидана конструкција преовладала у грађењу јавних и репрезентативних објеката. Усвајање масивног система градње није значило и потпуно напуштање бондрука у грађењу стамбених зграда. Новоформирано сиромашно градско становништво градило је своје куће на начин који су познавали из сеоских средина из којих су дошли, а ту је бондручна конструкција била најзаступљенија.

Зграде подигнуте за време владавине кнеза Милоша могу се, према начину грађења, поделити у две групе. Прву групу представљају државна здања и објекти грађени за потребе кнеза, као и куће богатијих Београђана. Они су зидани од чврстог материјала: камена и опеке, и многи су сачувани до данашњих дана. Другу групу чине куће обичног грађанства, које су грађене трошним материјалом, у бондручном систему са испуном од ћерпича и блатним малтером као везивом, или као плетаре. Облепљиване су блатом (чаймом), а затим кречене. Овакав конструктивни склоп је масовно примењиван, али због несолидног материјала зграде нису опстале до данашњих дана.

\section{1. Грађење по традиционалном принципу - примена бондручне конструкције}

Период одмах после Другог српског устанка и почетак владавине кнеза Милоша обележило је грађење у духу оријенталне архитектуре, која је била дубоко укорењена на овим просторима, услед турске вишевековне

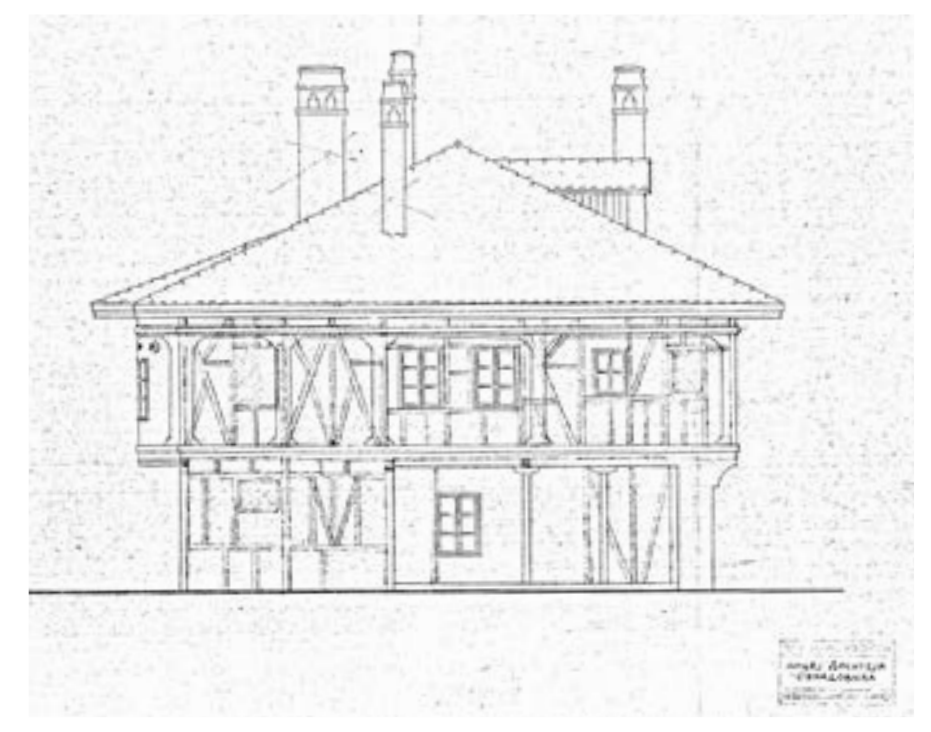

Сл. 2 / Досииејев лииеј, бочна фасаяа са уирйаним расйореgом бондручних елеменайа (gокуменйација ЗЗСКГБ) превласти. Прихватање познатих модела није одликовало само архитектонско обликовање; континуитет је постојао и у примени традиционалних конструктивних система и техника грађења. Наставак примене бондручне конструкције, као тековине претходног периода, последица је непознавања нових техника грађења и недостатка домаће обучене радне снаге која би градила по новом систему. У другим европским градовима преовладавала је масивна градња опеком као грађевинским материјалом, али је такав конструктивни систем прихваћен у Србији тек двадесет година касније. Бондручни конструктивни склоп захтевао је најмање улагања, користили су расположив материјал, а домаћи мајстори били су вични у грађењу оваквих кућа.

Развој технике грађења у домаћем градитељству, по тумачењу познатог социолога Сретена Вукосављевића, није увек ишао од простије ка сложенијој: Косииур, склои сомића, можgанаи, унизе и усеии, жујиче, разна уклайања и ужљебљавања, сав ииај симарински сељачки начин везиваға ірађевной материјала био је финији ов нове теххнике ирикивања. Еволуиија ірађевнои

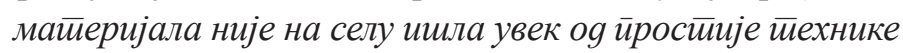
сложенијој. Сељак је врло сйоро ирримао нову иракииичнију и бржу иеехнику везивања їрађевної майеријала; gржао се сииаре, gаніуубне и сложене.

Несолидност материјала од којег су направљене бондручне куће утицао је на то да данас у Београду постоји само неколико очуваних објеката грађених у овом конструктивном систему. Примери градских кућа оријенталног типа грађених за време Турака који сведоче о традиционалном начину грађења у бондручном систему јесу: Доситејев лицеј и Манакова кућа, а из периода владавине кнеза Милоша сачувана је зграда у којој је кафана „?““ и кућа породице Најдановић.

Доситејев лицеј је највероватније саграђен у другој половини 18. века као стамбена кућа имућне турске породице, да би почетком 19. века променио функцију и постао Велика школа, прва виша просветна установа у Србији. Грађен је у бондручном конструктивном систему, са скелетом од храстових греда и испуном од опеке у кречном малтеру. ${ }^{8}$ Оваква испуна примењена је на спратној етажи, док су зидови приземља грађени у бондруку са испуном од камене ситнежи у блату. ${ }^{9}$ Распоред елемената скелетне конструкције установљен је приликом реконструкције објекта и може се констатовати да систем у одређеним сегментима одступа од уобичајеног, једноставног, симетричног ритма бондручне конструкције. Елементи који укрућују правоугаона поља и уоквирују прозорске елементе такође су постављени без јасних правила, што упућује да је склоп 
ових елемената формиран у току грађења и прилагођаван расположивом материјалу (сл. 2). Међуспратна и таванска конструкција су формиране од борових греда и обложене даскама и профилисаним лајснама. Спрат објекта са уличне стране је конзолно препуштен у односу на приземну раван, што је произвело специфично решење детаља конструкције и обраде еркера (сл. 3). Кровна конструкција је направљена од храстових греда у поједностављеном систему крова са столицама где склоп чине рожњаче, рогови и ступци-подупирачи, без косника и везача. Четвороводни кров с дубоким стрехама покривен је ћерамидом, што је типичан начин грађења на подручју Балкана.

\section{2. Прелазни период - мешавина традиционал- них и савремених техника грађења}

Тридесете године 19. века представљају период интензивне градње, кад почињу да се испољавају утицаји нових техника грађења и архитектонских стилова из Европе, који постепено потискују традиционалну, народну, оријенталну архитектуру и старе технике грађења. Овај период у српској архитектури и грађевинарству Богдан Несторовић назива йериоg усклађивања и йериоg йрейоpoga ${ }^{10}$ Као резултат колебања и превирања настајали су објекти који имају одлике прелазног типа, где су сачувани неки елементи старог, али и усвајани и примењивани елементи новог начина обликовања и грађења. Нове технике грађења у масивној зиданој конструкцији нису доследно прихваћене на начин који је карактеристичан за средњоевропске земље, на које се наше грађевинарство угледало. Конструктивни склоп зграда грађених у овом периоду, које су подизане под кнежевом ингеренцијом, показује одлике прелазног типа, мешавину масивне зидане конструкције печеном циглом и бондручне конструкције. Темељи и подрумски зидови зидају се и даље каменом, приземни су често зидани у комбинацији камена и цигле, а зидови спрата зидају се искључиво од цигле. Напушта се коришћење ћерпича као зидне испуне у бондручном систему и користи печена цигла устаљених димензија између 30 цм и 35 цм дужине. Дрвени скелет је још неко време примењиван, вероватно зато што домаћи мајстори нису имали искуства у новом начину грађења. Спољашњи и унутрашњи зидови укрућивани су дрвеним ступцима, гредама и косницима, иако је зидна испуна од печене цигле била дебља, масивнија и конструктивно стабилнија. ${ }^{11}$

Пример прелазног типа конструкције је конструктивни склоп Конака кнегиње Љубице, који је грађен скромним средствима и примитивном техником, између 1829. и 1831. године. Фасадни зидови објекта

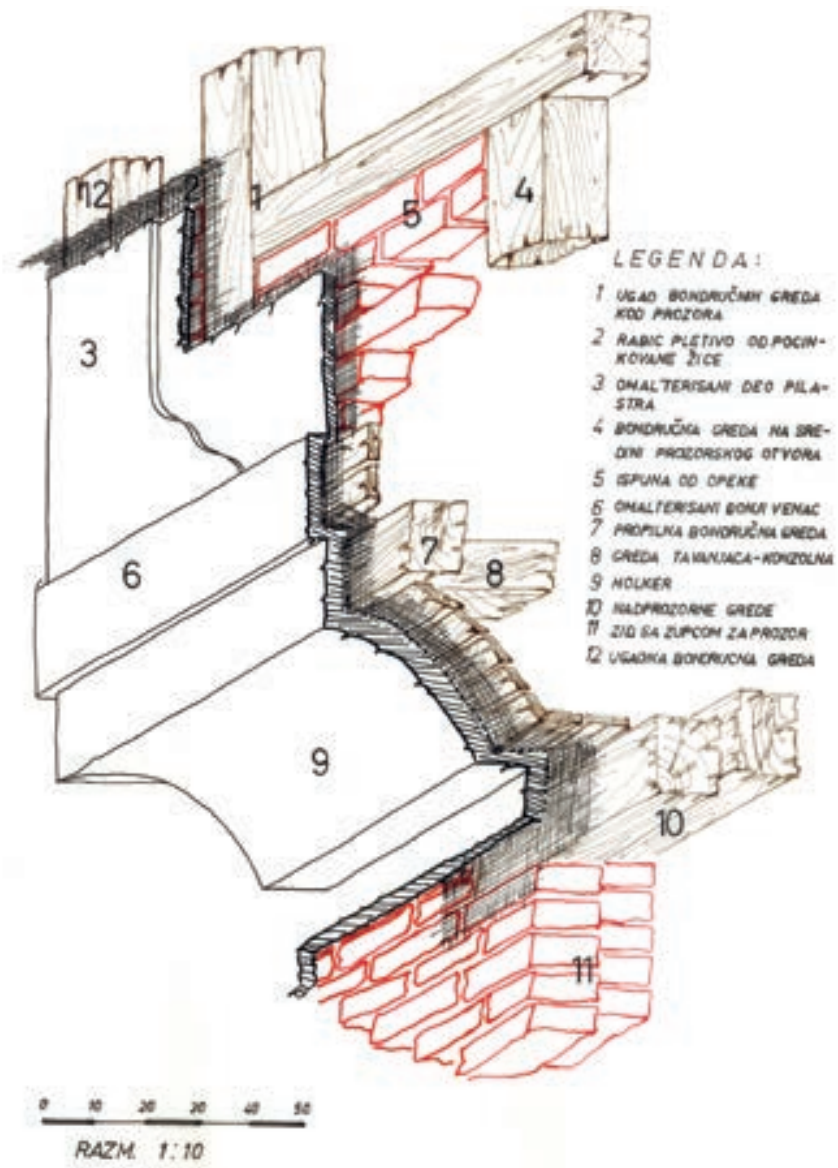

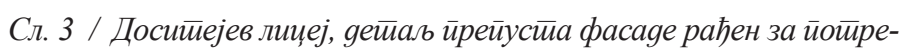

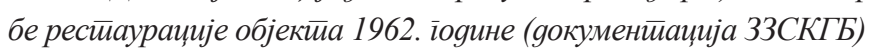

грађени су у комбинацији дрвеног бондрука и масивног зиданог склопа. Наиме, поред зидане испуне између дрвеног скелета, озидан је и додатни слој опеке у спољном зиду и на тај начин скривена дрвена конструкција. С временом је дрвена конструкција иструлила, али је зидани зид постепено преузимао комплетно оптерећење, тако да су се оштећења појавила само на угловима објекта, где је зидна маса, поред стубаца, пресечена и косницима бондрука. ${ }^{12}$

Унутрашњи зидови грађени су у чистом бондручном систему. Темељни и подрумски зидови, као и сокле, зидани су притесаним ташмајданским каменом са употребом дрвених, храстових сантрача и то, како сам кнез заповеда, висином gо колена, gа у случају ако би

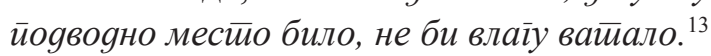

Међуспратну конструкцију изнад подрумске етаже чине сводови и лукови од опеке, ослоњени на камене ступце и пиластре. Оваква таваница изграђена је и изнад приземља Ђумрукане, у којем су магазе на своgове безбеgни og вайре. ${ }^{14}$ Остале међуспратне таванице на Конаку су формиране од храстових греда, које су 


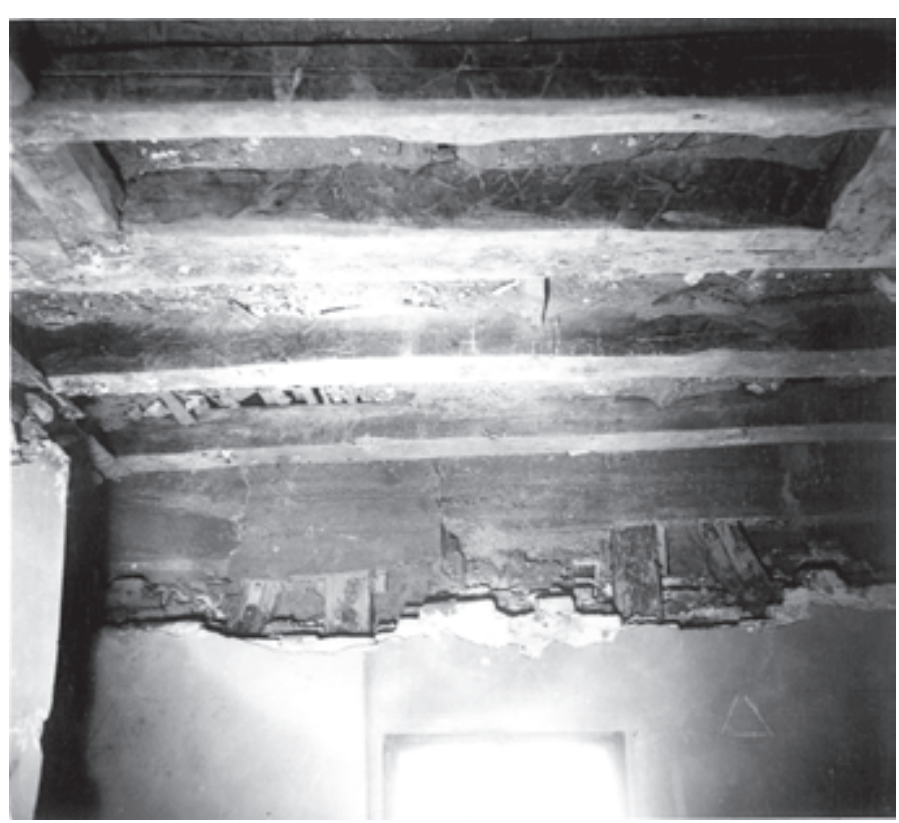

Сл. 4 / Конак кнеїие Љубице, међусирайна дрвена йаваница и фасаяни зия снимљени ирре извриених рестиаурайорских раяова (докуменйација З3СКГБ)

с временом претрпеле знатна оштећења (сл. 4). Кров је традиционалан, четвороводан с дубоком стрехом, изграђен од храстове грађе и покривен ћерамидом (сл. 5).

Прелазни конструктивни склоп препознајемо и на Конаку кнеза Милоша у Топчидеру (грађен 1831-1834. године), као и на Божићевој кући (грађена 1836. године).

Несигурност у примени новог зиданог масивног склопа сагледава се из писма Хаџи Николе Живковића кнезу Милошу, 1834. године, о радовима извршеним на Ђумрукани и недоумицама у вези са зидањем надземне етаже. Препознају се два могућа конструктивна приступа која је неимар предложио кнезу. Пошто су пред зиму направљени сводови и завршена доња етажа, Хаџи Ни-

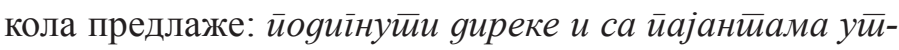
верgити и, а затим покрити како би се заштитио доњи ниво преко зиме. На пролеће зайочетии gиреке са изи-

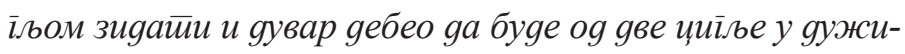
ну. Он наговара кнеза да прихвати овакво решење са дрвеним стубовима на спрату јер нишйа не би шкояило а gобро би било. Друго решење: ако ваша Свейлосй не о ообри диреке уgаритии већ сав іорюи бој gа буgе са и̧ийьама без gирека, йо ове јесени совериити не можемо, јербо яок се све не созияа йокрийи се не може. ${ }^{15}$

Очигледно је да зидане конструкције без дрвених ојачања у то време представљају делимичну непознаницу, док је бондручна конструкција с дебљом зиданом испуном сигурније решење, које познају домаћи градитељи и за које се лакше опредељују.

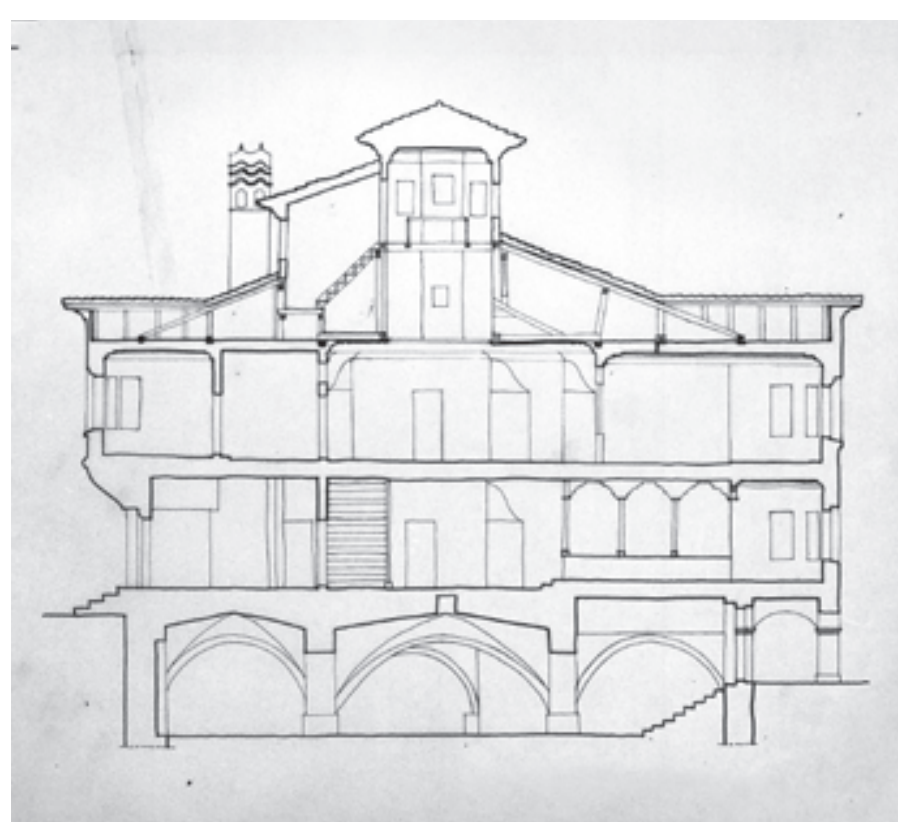

Сл. 5 / Конак кнеїиње Љубице: йоиречни ирресек (докуменйација 33СКГБ)

\section{3. Завршни период - усвајање масивне зидане конструкције}

Прихватање европских узора у обликовању архитектонских грађевина и масивне конструкције као савременог модела грађења примењено је најпре на државним објектима, грађеним од средине тридесетих година 19. века. Царинарница - Ђумрукана, грађена 1834-1835. године, сматра се првом зградом у Београду која има одлике европске архитектуре. Градиле су је тајфе Цинцара и домаћих мајстора, без учешћа радне снаге из Аустрије, које су већ имале дугу традицију у зиданим конструкцијама. Поред Ђумрукане, значајни објекти овог периода су: Дворац у Савамали, Зграда Совјета, Велика касарна.

Промене у грађењу државних и јавних објеката одразиле су се и на грађење стамбених кућа виђенијих и имућнијих грађана. Најближи сарадници кнеза Милоша подижу себи куће које су у потпуности изведене према западноевропским узорима: кућа Цветка Рајовића, управитеља вароши, Аврама Петронијевића, Томе Вучића Перишића, Јеврема Обреновића, Франца Јанкеа и других. На овим кућама примењени су у потпуности средњоевропски принципи архитектонског обликовања, просторне концепције и конструктивног решења. Објекти су грађени у масивном конструктивном склопу са зидовима од опеке или камена. 
Паралелно с репрезентативним државним и приватним објектима у Београду се граде куће обичног грађанства, другачије по својој концепцији, архитектонском обликовању и конструкцији. Пораст броја становника Београда после Другог српског устанка повећао је и појачао грађевинску делатност. Новопридошло градско становништво досељено је махом из сеоских средина и живело је у оскудици, што се непосредно одразило на објекте које су за себе подизали. За разлику од кућа богатих Београђана, прављених сада већ у потпуности по европским узорима, куће сиромашног грађанства представљале су пренесени модел сеоске бондручаре уграђен у градску матрицу. Оскудица и цена грађевинског материјала те недостатак стручне радне снаге условили су да се куће обичног грађанства граде у бондручном систему, који су сви познавали и који није захтевао превелика улагања. О присутности традиционалног система грађења и пола века касније сведочи нам Закон ірађевински за варош Беоїраg, усвојен 1896. године, а који предвиђа могућност грађења кућа у бондручном систему, али са обавезним каменим подзидом. У време кад су грађене куће по европским узорима и кровови покривани црепом или ћерамидом, велики број кућа по Србији и даље је покриван сламом, кровином или шиндром. Пошто су пожари били чести, због отворених огњишта и неотпорних материјала, издата је наредба о забрани коришћења ових покривача још двадесетих година 19. века. Кнез Милош је наређивао: ко іо о није gо саg йокрио свој gом с ћерамияом или gаском gа има gо gва месеиа йокрийи, и који не би хойио gа му се кућа развали. ${ }^{16}$ Пошто наредба није поштована, 1834. године Суд народни српски издао је Уреgбу за іамење йожара, којом се забрањује примена сламе и кровине за покривање кровова.

\section{Одлике масивног зиданог склопа и њихова примена у домаћој архитектонској пракси}

Средином 19. века масивна зидана конструкција постаје доминантан систем грађења, а бондручна конструкција се задржава у градњи кућа сиромашног градског становништва и у сеоским срединама. Масивни систем грађења, где је опека основни материјал за израду зидова, преовлађиваће у изградњи стамбених објеката све до шездесетих година 20. века, кад почиње масовније да се примењује скелетна конструкција.

У време кад Србија прихвата масивну зидану конструкцију, у Европи и Америци гвожђе постаје материјал нове индустријске епохе, која напушта дотадашњи традиционални начин грађења. ${ }^{17}$ Међутим,

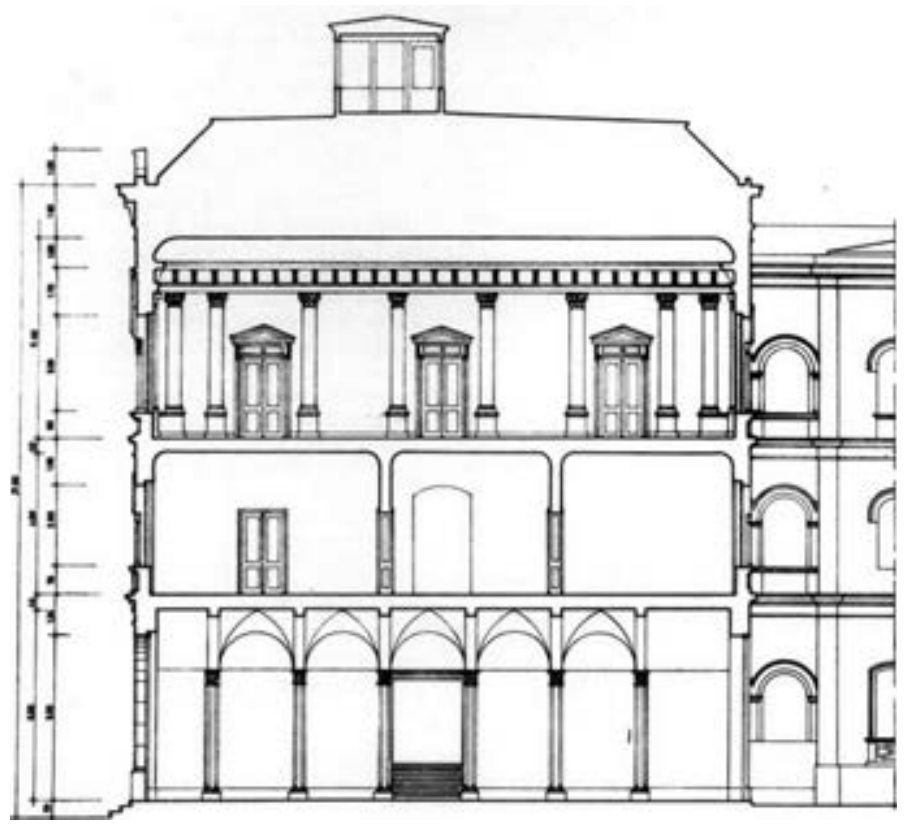

Сл. 6 / Кайетиан Мишино зяање, йоиречни ирресек кроз вестиибил и gворану (докуменӣација ЗЗСКГБ)

нова техничка достигнућа и инжењерске конструкције које је афирмисао нови материјал нису имали одјека у домаћој архитектонској пракси тог времена. Примена елемената од гвожђа у српској архитектури ограничена је на поједине сегменте конструкције: најчешће ребра или греде код таваница, а ређе стубове, као и за израду металних конзола, ограда балкона и степеништа. Архитекта Јан Неволе применио је гвоздене ливене стубове у холу Капетан Мишиног здања, грађеног 1862 1863. године, као и на згради старе Војне академије. У холу Капетан Мишиног здања таваница је формирана од крстастих надвишених сводова који се ослањају на полукружне лукове, постављене на стубове од ливеног гвожђа (сл. 6) ${ }^{18}$. Архитекта Димитрије Т. Леко поставио је гвоздене стубове на местима великих отвора у масивним зидовима на новој згради Војне академије (саграђеној између 1898. и 1900. године), и прихватио међуспратну конструкцију гвозденим гредама (сл. 7).

Књига Емилијана Јосимовића Грађанска архииеек$\bar{u} y р а$ и ірађење йуйова, издата 1860 . године, значајна је као сведочанство техника и правила грађења који су примењивани средином 19. века у Србији. То је прва књига из области архитектонских конструкција написана на српском језику и служила је као уџбеник из предмета Грађанска архитектура, који је постојао као редован предмет на Лицеју од 1841. године. ${ }^{19}$ У поглављу Дуіовечносй зданија аутор обрађује: грађу, темеље, горње зидове, патосе, таване и сводове, а у последњем делу кровове кућа. У књизи је наведено да се масивни зидови граде од 
цигле која нема устаљене димензије, али аутор истиче да

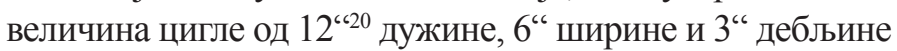
йоgаје ири зияању и рачунању велику удобности. ${ }^{21}$

Описујући могуће начине прављења цигле, Емилијан Јосимовић у поменутој књизи наводи: ичиіьье йраве се на двојаки начин, йо јести или самим рукама йомоћу калуйа на астиалима, или йак с машинама. Машине уйойребљују се с користии онgе, їgе или влаgа оскуgица у раяницима, или їgе се йако мноїо ичиїала тироши, gа ни велики број руку зайо јошйе не достинже. ${ }^{22}$

Темељи се праве од опеке или камена и то тако да њихова ширина мора бити већа за пола стопе од зида прве етаже, а уколико су од камена неправилног облика, за стопу. Уколико је тло слабије носивости, постављају се роштиљи од дрвених греда, а кад је носивост тла била изузетно лоша, побијани су дрвени шипови.

Међуспратну конструкцију изнад подрума, а понекад и приземља (уколико зграда има више етажа), чине сводови зидани од камена или опеке. Најчешће се примењују полуобличасти или крстасти сводови.

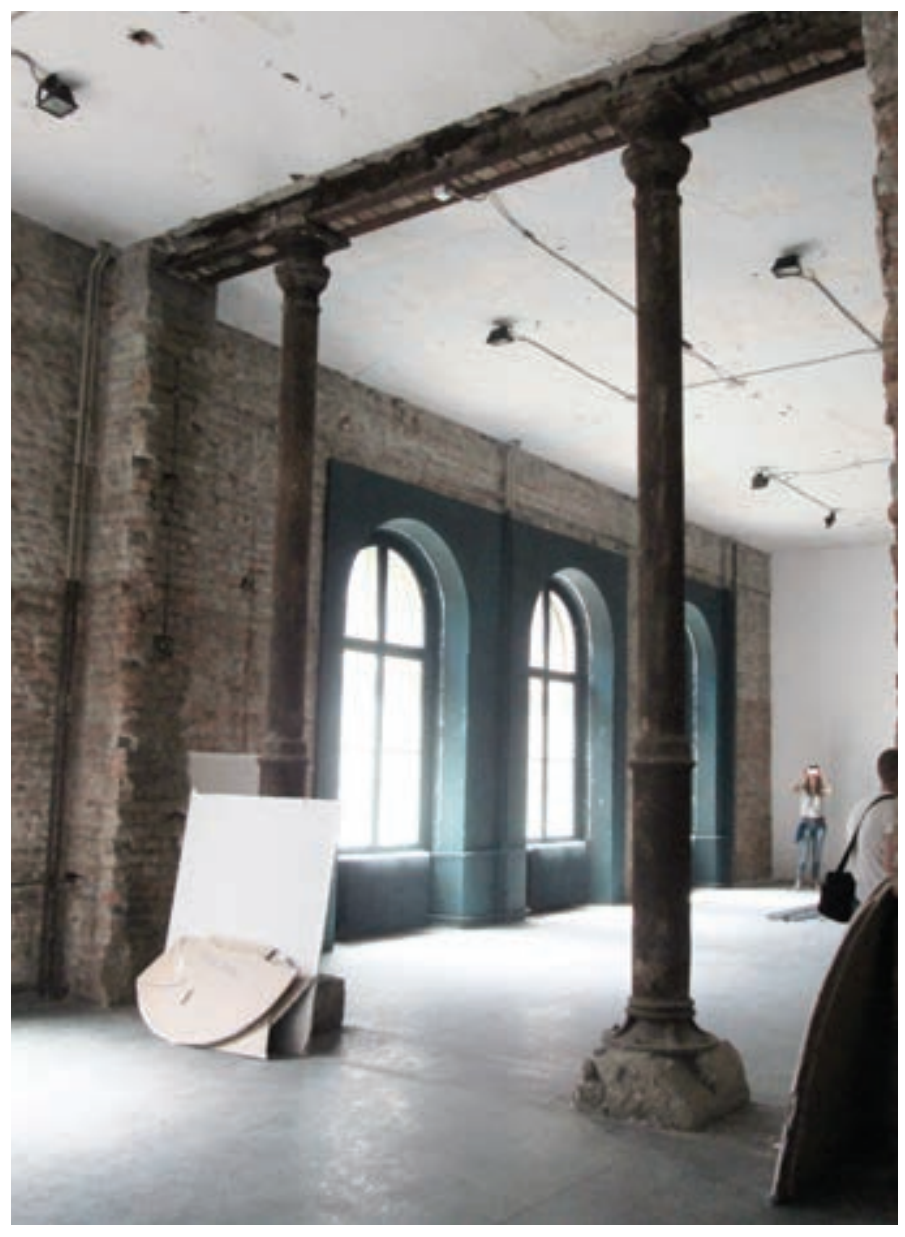

Сл. 7 / Гвозgеноливени сииубови у зіраяи Нове војне акаgемије (фойоїрафија М. Ройер Блаїојевић)
Према Емилијану Јосимовићу, кровови се у зависности од нагиба кровних равни деле на: немачке (где је висина крова једнака удаљењу од венца до слемена), италијанске (висина крова једнака је једној трећини или две трећине удаљења од венца до слемена) и холандске, који уместо рогова имају лукове од дасака. Коментаришући различите нагибе кровова, Јосимовић наводи да су стрми кровови, иако бољи за одвођење воде с крова, нерационални јер се троши више дрвене грађе и оптерећење доње конструкције је веће, а да су кровови блажег нагиба без сваке сумње лейши, али да се морају пројектовати тако да не долази до задржавања воде или снега.

Међуспратна конструкција ка таванском простору израђује се од дрвета и могућа су два начина њене израде. Први начин подразумева постављање дрвених греда на конструктивне зидове без међусобног размака и повезивање дрвеним клиновима. Са доње стране овако формиране таванице прикива се трска, преко које се поставља малтер. Други начин формирања међуспратне конструкције је постављање дрвених греда на међусобном размаку од две и по до три стопе и прикивање дасака са доње стране. Уколико се плафон малтерише, за даске се прикуцава трска, која је подлога за малтер. Друга могућност испуњавања простора између тавањача које су постављене на растојању јесте убацивање омоти og сламе (око летве намотана усукана слама), који се углављује у греде, тако да заједно с њима формира равну хоризонталну површину са доње стране, на коју се затим поставља малтер. Први начин формирања таванице је квалитетнији али и скупљи, с великим утрошком дрвене грађе, па се зато ретко примењивао.

Приликом постављања прозора поштују се правила симетрије тако да йрозори свакої їорњеї боја йреба gа се налазе уйраво наg йрозорима дольеїа боја, среgа наg среgом; никаg gакле не сме gоћи наg ирозором gольеїа боја у іорњему зия. ${ }^{23} \mathrm{У}$ погледу примене двоструких прозора наводи се њихов значај у зимском периоду, као уштеда при грејању, и наглашава да спољни оквири морају бити од квалитетног материјала и с највећом брижљивошћу израђени. Њихова улога је да: сйољни сйуgени возgух, с оним који међу собом закључују, оgлуче оg собноїа возяуха, како се овај не би брзо излаяио. ${ }^{24}$

Материјал за израду степеница је дрво, камен или гвожђе. Као предности за примену камена и гвожђа наводе се већа постојаност у пожару, већа носивост и то што се пењући се по њима не причињава толика лупа као по дрвеним. 
Препознат је значај односа ширине и висине газишта, потреба да сви степеници буду истих димензија, као и да степениште треба да буде у простору које је зидовима одвојено од других простора, никако у непосредној вези с кухињом или простором за ложење.

Подови у стамбеним просторијама облажу се најчешће дрвеним облогама: даскама од јеле или смрче, или паркетом. Даске се постављају на дрвене потпатоснице, између којих се простор испуњава песком или шутом. Паркет је подна облога у богатијим кућама и поставља се на подлогу од неоструганих дасака. Камен и цигла као подна облога примењују се у просторијама које морају бити безбедне од пожара или у којима се користи вода.

Куће грађене у овом периоду најчешће су приземне или једноспратне. Какво је мишљење владало о зидању високих објеката најсликовитије описује Емилијан Јосимовић: Виша зgанија оg йри боја неисиилаћују се, а за зяравље су обитиаиељь виши бојеви врло шкояљиви, збой чеїа се йо млойим местиима у Евройи иоолицајно забрағују. ${ }^{25}$

\section{Стамбена изградња у Београду у другој половини 19. и почетком 20. века}

Убрзани развој града крајем 19. и почетком 20. века, велики прилив становништва из сеоских подручја у Београд, наметнуо је потребу градње колективних станова. Први примери вишепородичног становања јавили су се већ средином 19. века, али су били малих димензија, да би се почетком 20. века интензивирала изградња вишеспратних објеката и $c \bar{m} а м-$

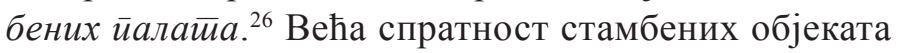
карактеристична је за центар града, где се обично граде пословно-стамбене зграде с локалима у приземљу и становима на спрату, али је њихова заступљеност у укупном стамбеном фонду била незнатна. ${ }^{27}$ Оваква структура, с приземним зградама заступљеним у великом проценту, знатно се разликовала од других европских модерних градова.

Колективно становање на подручју Београда развијало се у неколико праваца: изградња станова за тржиште, изградња најамних станова и изградња социјалних станова. Инвеститори изградње станова за тржиште биле су најчешће банке или задруге, које су свој новац улагале и у изградњу станова за изнајмљивање, и захваљујући њима настале су прве колективне вишеспратнице. С обзиром на чињеницу да је потражња станова била велика, а да држава није довољно економски подстицала изградњу вишеспратница, недостајао је капитал за такво инвестирање и колективно становање се у овом периоду развијало у правцу јефтиних, нефункционалних и некомфорних дворишних станова. Тада настаје специфичан начин колективне стамбене изградње, који није имао узора у западноевропским градовима, а који је одговарао економским приликама становника Београда. Поред богатих финансијера изградње најамних станова, појављује се слој обичног грађанства који у оквиру својих приватних парцела гради станове за изнајмљивање. Описујући тадашњи начин становања, Дубравка Стојановић уводи назив ваїон системм, којим описује изградњу приземних приватних најамних станова где се линијски смењују соба и кухиња. ${ }^{28}$ Овакво грађење је обично настајало у неколико етапа, колико је дозвољавала дубина парцеле, и на тај начин створен је велики број малих дворишних станова који најчешће нису задовољавали основне хигијенске услове, потребе за осунчањем и проветравањем.

Изградња социјалних станова започела је у периоду пред Први светски рат реализацијом колективних зграда за становање радника, које је финансирала Београдска општина. ${ }^{29}$ Саграђене су 1911. године у Радничкој улици (данас Венизелосова), по пројекту Јелисавете Начић. Ови објекти су сачувани до данашњих дана и представљају репрезентативни пример колективног становања с почетка века.

\section{Развој конструктивних система и техника грађења крајем 19. и почетком 20. века}

У Србији се крајем 19. века користи само пуна опека. Њен формат је прописан тек 1896. године, а до тада су димензије опеке најчешће биле условљене устаљеним производним поступком конкретне циглане или црепаре. Често се и у већим местима разликују димензије опеке у зависности од произвођача. Драгутин С. Милутиновић, професор Велике школе у Београду, у својој књизи Наука о ірађи из 1894. године, истиче важност међусобне сразмере димензија опеке и приказује формуле помоћу којих је потребно извршити димензионисање. Према његовим формулама, ширина опеке требало би да буде једнака двострукој дебљини увећаној за величину малтерске спојнице. Дужина опеке требало би да одговара двострукој ширини увећаној за величину малтерске спојнице. Он напомиње да је у Србији у то време био прописан формат зидних опека само за железничке зграде. ${ }^{30}$ У Француској, Баварској и Аустрији димензије опеке биле су стандардизоване на нивоу града или области, а једино је у Пруској постојао јединствен формат, који се морао примењивати за сва нова државна здања. 

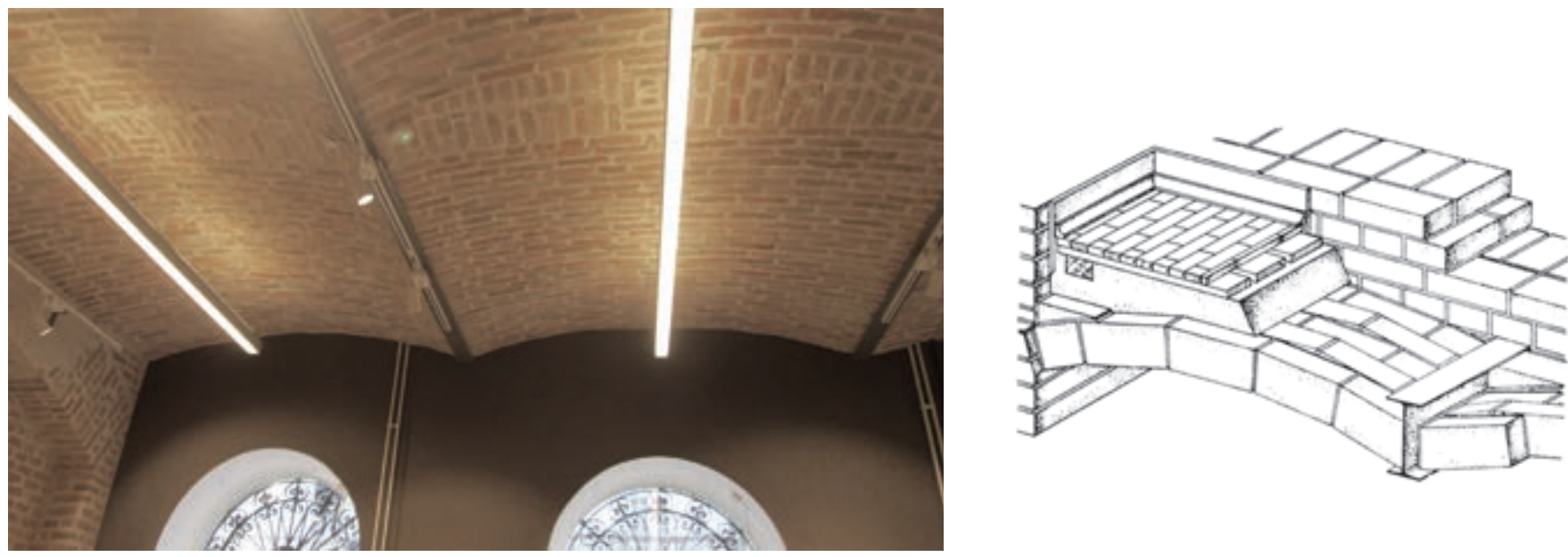

Сл. 8 / Пруски своg (фойоїрафија М. Ройер Блайојевић; ириееж П. Крстиић 1982: 8)

У европским земљама које су имале дужу традицију у производњи и примени опекарских елемената, као што су: Енглеска, Пруска, Француска, Холандија, Италија, Аустрија, коришћене су и друге врсте опека: клинкер, шупље, шамотне, опеке за облагање, призмасте и коничне, плочасте, фасонске опеке. Постојала су и иновативна решења жлебљених опека, које се међусобно тако уклапају да није потребан малтер као везивно средство. Оваква решења нису заживела, али показују ниво техничких достигнућа опекарске производње у развијеним европским земљама. Иако је стручна јавност у Србији била упозната с њиховим дометима, технологија производње опеке, развој домаће индустрије, али и низак ниво техничке свести онемогућавали су достизање европских резултата.

Средином 19. века, с применом машина које под притиском истискују глинену масу кроз калупе, започиње производња шупље опеке. Инжењер Бори (Jules Borie) производио је са својим братом ошупљене глинене елементе и примењивао их на објектима у Паризу средином 19. века. Године 1876. патентирао је у Америци шупљу опеку са уздужним каналима, коју су називали иреіррађена оиека. Производња ошупљених елемената од глине није усредсређена само на зидове; појављују се у то време и таваничне испуне које се умећу између дрвених греда, степенишна газишта произведена на исти начин, покривни елементи на оградама и слично. Међутим, тековине европске опекарске индустрије нису нашле одјека у Србији у 19. веку и једини глинени производ за зидање који се у то време примењује је пуна опека.

Кровови се најчешће покривају равним црепом или ћерамидом. Квалитетни црепови прављени су у Панчеву и Апатину и они су често коришћени на згра- дама у Београду. Ни димензије равних црепова, као ни опеке, нису стандардизоване и варирају: дужина 35-40 цм, ширина 13-18 цм и дебљина $1,2-1,5$ цм. У Европи се у то време праве равни црепови с различитим завршецима; поред стандардног лучног, производе се угаони и равни, што и данас представља реткост у понуди домаћих произвођача. Од фасонских елемената производе се полуцрепови који се користе код покривања увала. Ћерамида која се производила у Србији имала је попречни пресек сегмента кружнице и различите ширине на крајевима. Она је јефтинија од црепа зато што је присутна на овим просторима дуги низ година и технологија њене израде позната је домаћим мајсторима. Ћерамида је, по речима Драгутина Милутиновића, одомаћена у свим крајевима Србије, али је све више потискује раван цреп. Њене димензије се разликују у зависности од краја где се производи, али им је заједничко то, како наводи Милутиновић, ga je свуga ираве тиако іломазну и нейравилноїа облика, gа се она може сматирайи као најнесавршенији фабрикай керамичке инуустирије. ${ }^{31}$

Проналазак машине за пресовање глине омогућио је формирање сложеније профилације елемената и то је убрзо изнедрило појаву жлебљених црепова. Према Лефевру, преломна година у производњи црепова је 1851, кад су браћа Жилардони изумели нову врсту покривача који превазилази недостатке равног црепа. Жлебљени цреп је био једноставнији за постављање, лакши од равног, са спојевима отпорнијим на атмосферске утицаје. ${ }^{32}$ Различите варијанте овог покривача убрзо су се појавиле и у другим земљама које су предњачиле у производњи глинених елемената. Међутим, у Србији до краја 19. века нису прављени жлебљени црепови. 

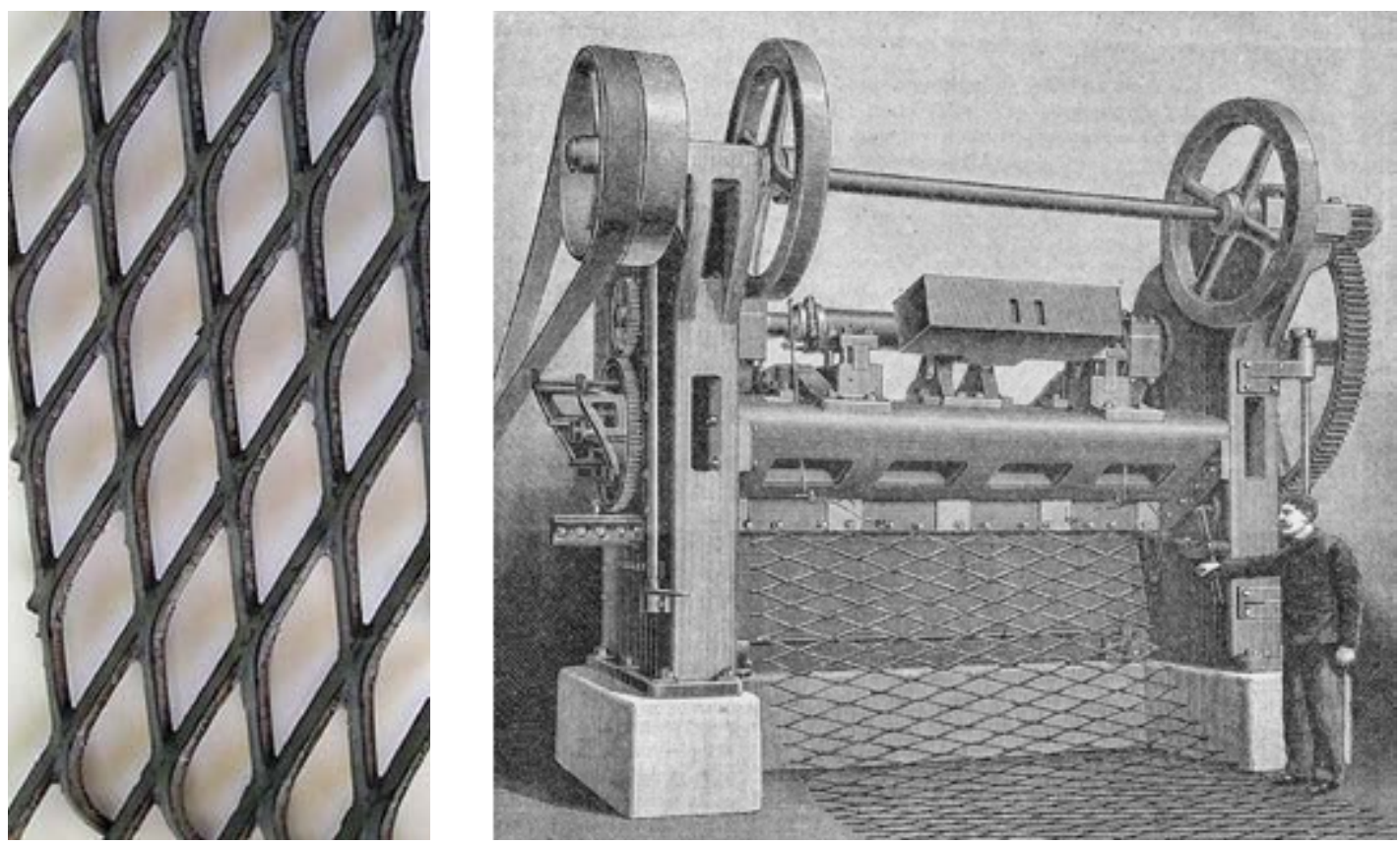

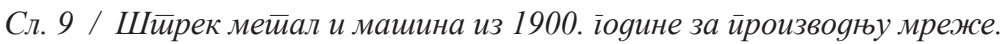

Извор: https://de.wikipedia.org/wiki/Streckmetall [30. 3. 2017]

Таваница изнад подрумских просторија морала је бити противпожарна и у овом периоду, у градњи стамбених објеката, најчешће се примењује сегментни, плитки ируски свод зидан обичном опеком и ослоњен на гвоздене греде. Стрела свода је 1/10-1/12 распона, а греде се постављају на размаку 1-1,5 м како би се штедело на скупом гвозденом материјалу (сл. 8). Таванице изнад виших етажа биле су формиране од дрвених греда, постављених на међусобном размаку, преко којих су прикуцаване даске. Уколико се простор користио за боравак, преко дасака се насипао песак и постављале су се потпатоснице као носачи дрвеног пода, а уколико је етажа била таванска, преко дасака се постављао слој блата.

\section{Појава новог материјала - армираног бетона и његова примена на београдским грађевинама}

У другој половини 19. века појавио се нов материјал, армирани бетон, који ће у потпуности променити дотадашњи развој конструкција. Захваљујући армираном бетону, развиће се нов начин фундирања, формирања зидова, нов начин конструисања међуспратних конструкција. ${ }^{33}$

Упознавање српских грађевинара с новим материјалом започето је крајем 19. и почетком 20. века кроз чланке у стручним часописима. Почетак примене армираног бетона у грађењу београдских зграда не може се сасвим прецизно одредити. Архитекта Ни- кола Несторовић, савременик тог доба, у својој књи-

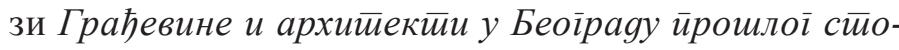
лећа, наводи да је претеча примене армираног бетона код нас била таваница Управе фондова (данашњи Народни музеј). ${ }^{34}$ Зграда је изграђена 1903. године по пројекту Николе Несторовића и Андре Стевановића. На овој згради је први пут примењен шиирек мейал, метална мрежа постављена између гвоздених греда у слоју бетона дебљине 10 цм (сл. 9). ${ }^{35}$

Према истом аутору, прва зграда у Београду на којој је примењена армиранобетонска таваница био је Хотел „Гранд“, архитекте Милана Антоновића, саграђен 1904. године, а срушен средином шездесетих година прошлог века. ${ }^{36}$

Почетак примене армираног бетона у Србији изазвао је потресе у стручној јавности, пошто је Трговачки суд у Београду одобрио концесију фирми „Штајнлехнер“ за право на израду армираног бетона. ${ }^{37}$ Уследила је тужба Милана Антоновића на овакву одлуку, а затим и протест Удружења инжењера и архитеката, па је концесија повучена.

Примена новог материјала у првој деценији 20. века повезује се с радом архитекте Матије Шнајдера. Сматра се да је разлог његовог доласка из родне Баварске било увођење армираног бетона у грађевинску делатност Београда и Србије. ${ }^{38}$ Његов најзначајнији објекат, који је пројектовао и извео, била је Панђелина кућа, саграђена 1909. године, која је стајала на углу данашње 
Влајковићеве улице и Трга Николе Пашића, али је срушена 1955. приликом формирања Трга (тада Трг Маркса и Енгелса). Зграда је имала приземље и три спрата, а на плановима за овај објекат уцртана је ситноребраста армиранобетонска међуспратна конструкција. ${ }^{39}$ Поред овог објекта, Матија Шнајдер је извео армиранобетонске радове на најзначајнијим београдским грађевинама тог доба: Хотел „Москва“, Хотел „Бристол“, Палата Викторовића на Теразијама, темељи на Београдској задрузи, Фабрика Косте Илића и синова, таваница Биоскопа „Колосеум“ (касније ,Звезда“) и други.

Грађење зграде Београдске задруге на подводном и слабо носивом терену у Карађорђевој улици наметнуло је потребу израде темеља од армираног бетона. Зграда је грађена од 1905. до 1907. године и аутор објекта Никола Несторовић наводи да је тада први пут у Београду примењен армирани бетон у већем обиму. ${ }^{40}$ За његову израду коришћено је пљоште гвожђе, зато што код нас у то време није било арматуре кружног пресека. Подрумске просторије котларнице, које се налазе на најнижој коти, изоловане су премазима церезита, најбољом хидроизолацијом тог доба. Хидроизолациони премази рекламирани су у домаћим стручним часописима још крајем 19. века, али су ретко примењивани у домаћој пракси.

Грађење хотела „Москва“ од 1905. до 1907. године представљало је, у конструктивном смислу, захтеван подухват. Фундиран је на клизавом, слабо носивом терену па су темељи, стубови, таванице и степенице изведени у армираном бетону у систему Луиййолg $u$ Шнајgер из Штутгарта.

Грађење хотела „Бристол“, од 1910. до 1912. године, у непосредној близини Београдске задруге показало је исте проблеме с подводним тереном, који је мале носивости. С обзиром на то да је била предвиђена подрумска етажа испод читавог објекта, фундирање је овога пута извршено помоћу 900 бетонских шипова (система Шиеерн). Специфичност овог система је било то што су у земљу побијани храстови шипови обложени поцинкованим лимом, који је служио као изіуубљена оплата. Дрвени шипови су извлачени из земље, а у лимени калуп је сипан и набијан бетон. ${ }^{41}$ Преко њих изливена је бетонска плоча, а хидроизолација подова и зидова извршена је премазима церезита са унутрашње стране. Аутор Никола Несторовић тврди да се хидроизолација успешно одржала све до Првог светског рата, кад је зграда претрпела оштећења. ${ }^{42}$

Судећи по годинама почетка примене армираног бетона, Београд није заостајао за европским престоницама и нови материјал је релативно брзо усвојен.
Међутим, његово коришћење је било ограничено на комплексне, јавне објекте, сложене конструкције где је примена армираног бетона била неопходна. Са друге стране, велики број стамбених објеката и даље је грађен применом традиционалних материјала и техника грађења. Опека је и даље најзаступљенији материјал за израду зидова, а међуспратне конструкције су дрвене, или ређе од металних профила. Већа примена армираног бетона карактеристична је за међуратни период, а о масовној примени овог материјала може се говорити тек од шездесетих година прошлог века.

\section{Грађевински прописи}

Грађевинско законодавство јавља се у Европи у другој половини 19. века. Референтни законски прописи, који су регулисали проблеме противпожарне заштите, хигијенске услове становања, били су немачки и по узору на њихово законодавство настали су и наши први грађевински прописи. Закон ірађевински за варош Беоїраg усвојен је 11. децембра 1896. године и одредбе закона су у највећој мери садржале опште прописе за подизање грађевина, док је техничке податке о начину грађења у већој мери требало да дефинише предстојећи правилник. Оно што је у Закону дефинисано, а тиче се конкретног грађења јесте да се зграде од бондрука, ћерпича, набоја или плетаре не могу подизати са лица улице, а да је њихово грађење забрањено у главним трговачким улицама и по унутрашњости дворишта. На овај начин старе технике грађења су потискиване из градских средина и постепено напуштане.

Значајну одредбу Закона представља члан 21, којим су нормиране димензије цигле и на тај начин уведена правила у цигларску производњу. До краја 19. века њене димензије су се мењале и зависиле од појединачних циглана и њихових устаљених производних програма. Овим чланом Закона одређено је да нормална цигла мора имати дужину 29 цм, ширину 14 цм и дебљину 6,5 цм. Угледање на аустријски формат опеке логична је последица увоза и познавања овог материјала и његове примене на многим грађевинама Сpбије. Аустрија је имала дугу традицију у производњи цигле и квалитет њихових производа био је познат широм Европе.

Убрзо после доношења овог закона, прописан је и Грађевински ирравилник за варош Беоїраg, 1. марта 1897. године, који је детаљније објашњавао одредбе прописане Законом. Правилник је у првом поглављу

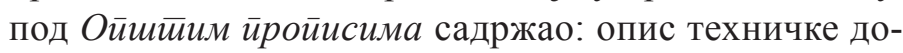
кументације која је неопходна за пријаву градње, пра- 
ва и обавезе општинских инжењера који врше надзор, постављање објекта у односу на регулациону линију. У овом делу прописано је да сваки објекат са уличне стране мора имати на стрехи положен или висећи олук од метала, или неког другог несагоривог и од воде непробојног материјала.

У другом делу под називом Пройиси за сйалносй ірађевина описане су техничке ставке којих се градитељ мора придржавати приликом изградње објеката. Прописане су дебљине зидова и то тако да главни зидови највише етаже морају бити најмање циглу и по дебели. Под главним зидовима подразумевају се спољашњи зидови, средњи носећи зидови и они у којима се налазе димњаци. ${ }^{43}$ У сваком нижем спрату зидови се подебљавају за половину цигле. Ови зидови могу кроз две етаже бити исте дебљине ако конструкција таванице то дозвољава. Главни зидови приземних зграда могу бити дебели једну циглу уколико је дубина собе максимално 5 м, а висина до 3,5 м. Средњи зидови највиших етажа морају имати дебљину једне цигле, а уколико је дубина собе преко 6 м, морају имати дебљину главних зидова. Њихова дебљина такође се повећавала на нижим етажама. Преградни зидови могу се правити од половине цигле уколико нису виши од 4,2 м ни дужи од 6 м. Прописана је и дебљина степенишних зидова: минимум једна цигла уколико се степеници узиђују са обе стране, или цигла и по уколико се узиђују само са једне стране. Ове одредбе важе уколико се зида циглом у кречном малтеру. Забрањено је постављати гвоздене греде на зидове који су тањи од цигле и по.

У трећем поглављу дефинисани су услови за грађење зграда од плетера (чатме) и у бондручном систему. Наведено је да се овако грађени објекти морају подзидати печеном опеком или каменом минимум 30 цм од коте терена. Огњишта и димњаци, као и зидови ка њима, морају бити изведени од тврдог материјала и омалтерисани.

У четвртом поглављу дати су противпожарни прописи и дефинисана дебљина зидова у таванском простору, око огњишта, ка суседном објекту, забатних и калканских зидова. Кровна конструкција мора бити подигнута од нивоа пода таванског простора минимум 15 цм, а тавањаче на последњој етажи морају бити покривене слојем земље или песка минимум 8 цм дебљине. Једна од значајних одредби је и да се сутерени и подруми морају засвоgити , а да се дрвена међуспратна конструкција, која је у то време најзаступљенија, може користити само изнад приземља и на вишим етажама. Највећи део Правилника посвећен је управо противпо- жарним прописима, што говори о потреби и значају ове проблематике у градњи објеката. Дефинисани су степенишни простори као издвојене целине и одређене су димензије степенишних елемената. Димњаци су такође детаљно прописани: пресек димњачких цеви, висина димњака изнад крова, њихова позиција у односу на дрвене греде, максималан број ложишних места и друго.

Дефинисане су димензије прозорских отвора и то тако да је њихова минимална површина у собама за боравак, где се простор непосредно осветљава, минимум 1/10 подне површине, а код посредног осветљавања најмање 1/5 подне површине. У просторијама за боравак морају постојати макар једна врата ширине један метар, а висине 2,2 м. Прописане су и димензије прозора са дворишне стране преко којих се осветљавају унутрашњи простори. На овај начин омогућено је и пројектовање светларника, што је утицало на већу изграђеност парцела и дозволило много гушћу изградњу. ${ }^{44}$

Пето поглавље названо је Пройиси у йойлеgу улейшавањ $а$ хиїијене. У овом делу одређени су естетски и санитарни критеријуми при пројектовању зграда. Како би се забранила градња ниских уџерица, прописана је минимална висина објекта од коте тротоара до нивоа стрехе од 3,85 м. Сутерени се могу користити за становање уколико је ниво пода максимално 1,5 м испод околног терена, а теме свода минимум 1,5 м изнад. Тавански простор се такође може користити за становање, али мора постојати степениште од несагоривог материјала које води до њега, околни зидови морају бити масивни и одвојени од дрвене конструкције крова. Таванице изнад последњег спрата морају бити толико јаке да могу издржати терет крова уколико се сруши у случају пожара.

У овом поглављу прописане су и мере заштите од влаге и наведено је да под приземне етаже мора бити минимум 50 цм подигнут од коте терена. Хигијена зграда дефинисана је и прописивањем положаја и димензија нужника, нужничких јама, помијара и сметлишта.

Закон грађевински за варош Београд, а касније и Правилник, представљали су прекретницу у даљој изградњи главног града. Најважнија промена је била та што се за грађење објеката морала добити грађевинска дозвола, која се издавала на основу прописане техничке документације, а коју је одобравао Грађевински одбор. Зграде су морале бити грађене на прописаној регулационој линији и морале су испуњавати одредбе у погледу противпожарне заштите, санитарне и естетске услове. Нова законска акта указују и на грађевинске прилике и 
проблеме са којима су се суочавали градитељи и корисници објеката, а требало је да буду регулисани овим прописима. Дивља градња у градском ткиву је један од проблема које је требало спречити доношењем нових прописа. Иако градња бондручних кућа овим актом није забрањена, регулисани су услови под којим се може градити у овом систему, а прописивањем минималне висине објеката спречено је прављење ниских, који су нарушавали изглед престонице. Велика пажња посвећена је противпожарним условима - прецизно су дефинисани сви елементи грађевине који су у контакту с ложиштима, који имају лоше противпожарне карактеристике, преко којих се пожар може даље преносити или који су значајни за евакуацију.

Правилником је предвиђено да се детаљи и статички прорачун раде за важније делове грађевине, али је зато стабилност зграде прецизно дефинисана прописаном дебљином зидова. На тај начин је спречено произвољно усвајање димензија од стране приучених извођача. Архив Грађевинског одбора, у којем је прикупљена техничка документација из периода 1898-1914. године, показује да је статички прорачун рађен само за челичне греде, што значи да су остали конструктивни елементи усвајани на основу Правилника (зидови) или искуствено (елементи од дрвета у таваници и крову). ${ }^{45}$

\section{НАПОМЕНЕ:}

1] У прилог томе говоре подаци да су се три пута промениле династије, шест пута владари, од којих су двојица убијена (Михаило и Александар Обреновић), један владар је абдицирао (Александар Карађорђевић), један је отеран (Милан Обреновић), а само кнез Милош је умро природном смрћу док је био на власти (Ристић 2003).

2] У Београду је 1834. године живело око 7000 становника, а тај број је удвостручен до 1846. године и надаље је бележио стални раст, изузев у периоду 1859-1863. године, што се објашњава пооштреним односима између Срба и Турака. Године 1874. у Београду је живело око 28000 становника, што значи да се њихов број четири пута увећао за 40 година (Радовановић 1974).

3] Назив цигла потиче од немачке речи ziegel и угледање на немачке узоре у градитељству довело је до усвајања овог термина у домаћем грађевинарству. Двадесетих година, у стручној литератури, већ је у употреби термин опека, али прецизан податак о томе када је напуштен стари назив није пронађен.

4] Петровић 1930.

5] Немачки правник Густав Раш на пропутовању кроз Београд наводи интензивну градитељску делатност која мења силуету града. Његова сведочења су значајна зато што је познавао Београд и из времена када су Турци живели у њему: Беоїpag је за йей йоgина йосйао евройски ірая. Највећи део йурской іраgа нестио је са земљине иовриине; свуgа су се иросеиале нове улице, уклањале рушевине, рушиле ярвене чайрье, іраgиле лейе евройске вишесирайнице, улице се иооилочавале, саяили

\section{Закључак}

Период до Првог светског рата представља време интензивног развоја техника грађења, примене нових конструктивних система и нових материјала. Усвајање масивне зидане конструкције, са опеком као основним материјалом, постаје традиционални модел грађења који ће преовлађивати у градњи породичних кућа током читавог 20. века и основна правила која су тада утврђена у великој мери су задржана до данашњих дана. Еволуција овог система сагледава се кроз промене у дебљинама зидова, међуспратним конструкцијама и начину финализације, али су базичне одлике грађења опеком остале непромењене током наредних сто година. Поред значајних промена у развоју техника грађења, у овом периоду су постављени темељи домаћег законодавства у области грађења и оформљена је домаћа индустрија грађевинских материјала, што је представљало основу за даљи развој грађевинарства у наредном периоду.

\section{доцент др Љиљана С. Ђукановић, архитекта Архитектонски факултет, Београд djuli@arh.bg.ac.rs}

ярвореgи, йоgизали йаркови, јеgном речи - Беоіраg се заоgевао у евройско рухо (Раш 2008: 64-65).

6] Вујовић 1986: 127.

7] Вукосављевић 1965.

8] Којић 1949

9] До 1962. године сматрало се да је приземље објекта зидано тесаним каменом, међутим, тада је утврђено да је и на овој етажи примењен бондручни систем грађења, што је представљало новину у сагледавању конструктивних карактеристика објекта (Маџаревић 1970).

10] Несторовић 2006: 43.

11] Павловић 1955.

12] Податак преузет из елабората Конака кнегиње Љубице, ЗЗСКГБ.

13] Петровић и др. 1966: 193.

14] Нав. дело: 231.

15] Истио: 256.

16] Ђорђевић 1946: 172.

17] Гвоздени носачи први пут се примењују у архитектонским објектима крајем 18. века, за израду међуспратних конструкција, а убрзо настају и скелетне конструкције од гвожђа.

18] Несторовић 1963.

19] Писана је, како и сам аутор наводи, йойуларно, зато што обим

${ }^{61}$ HACJE. 
наставе није омогућавао опширније градиво из ове области, а за комплексније изучавање било је потребно предзнање из других области, као што су математика, механика, геометрија, цртање, у чему су ученици ове школе оскудевали. Упознавање са главним начелима ове науке неопходно је, како сам аутор у предговору наводи, за стицање општег образовања полазника Лицеја, али и обичног грађанства да уколико нешто у будућности граде имају знања која ће им помоћи да са својом ірађевином раяости имају, а gа не буяужеришва йруби ирревара невешимих или безсавесних мајстиора (Јосимовић 1860: Предговор).

20] Ознака мере опеке представља палац или ияол и једнака је 2,63 цм.

21] Јосимовић 1860: 23.

22] Нав. дело: 21

23] Исйо: 65.

24] Истио: 81 .

25] Исйо: 63 .

26] Ротер-Благојевић 2006: 114

27] Година 1906-1907. направљен је детаљан попис београдских зграда и тада је евидентирано 82,7 одсто приземних кућа, 16,2 одсто једноспратних, 1 одсто двоспратних, 0,1 одсто троспратних и ниједна четвороспратница (Ђурић 1912).

28] Стојановић 2009.

29] Вуксановић-Мацура 2012.

30] Милутиновић 1894: 312.

31] Нав. gело: 355 .

32] Lefevre 1900.

\section{ЛИТЕРАТУРА:}

Вујовић, Б. (1986), Умейности обновљене Србије 1791-1848, Београд: Просвета и Републички завод за заштиту споменика културе.

Вукосављевић, С. (1965), Ист̄орија сељачкоі друшйва 2, Социолоїија стиановања, Београд: Српска академија наука и уметности.

Vuksanović-Macura, Z. (2012), Život na ivici : Stanovanje sirotinje u Beogradu 1919-1941, Beograd: Orion art.

Грађевински йравилник за варош Беоїраg (1897), Београд: Државна штампарија.

Ђорђевић, Т. (1946), Србија йре сйо іооина, Београд: Просвета.

Ђурић, Д. (1912), Пойис кућа и сиианова у Беоїраgу оg 6 новембра 1906. gо 15 марйа 1907, Београд: Штампарија Меркур Милорада Стефановића.

Ђурић-Замоло, Д. (1980), Беоїраg 1898-1914 : из архиве грађевинског одбора. Београд: Музеј града Београда.

Ђурић-Замоло, Д. (1981), Граяийељи Беоїраgа 1815-1914, Београд: Музеј града Београда.

Закон ірађевински за варош Беоіраg (1896), Београд : Државна штампарија.

Зборник закона и уреgаба у Краљевини Србији издайих оg 1. јануара 1896. gо краја истие іолине (1899), Београд: Краљевско-српске државне штампарије.
33] Архитекта Никола Несторовић, на чијим јавним објектима је први пут примењен армирани бетон, описује нови материјал на следећи начин: Бетион је ірађевински материјал

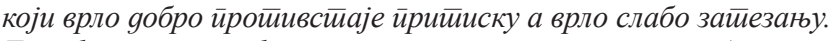
Гвожђе је йак ірађевински маиеријал који врло добро ироиивстиаје и иритииску и заиеезаюу, али збоі велике цене, иеешке обраяе и оіраниченостии иримене, юейова се уйойреба за извесне консиирукиије йоказала нераиионална. С йоїа је било йо-

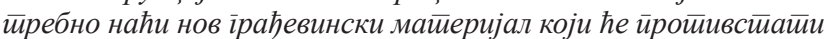
и йриииску и заиеезању и биии у иреимућсивву ная івожђем. Тај ірађевински маиеријал јесте армирани бейон, у коме бе-

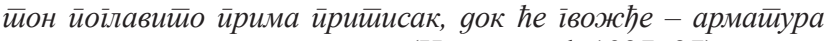

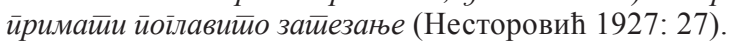

34] Несторовић 1972.

35] Штрек метал добија се исецањем металне табле и растезањем, тако да на крају добијена мрежа има међупросторе у облику ромбоида.

36] Несторовић 1972: 89.

37] Несторовић 2006: 271.

38] Према Ђурић-Замоло 1981: 108.

39] Ђурић-Замоло 1981: 374.

40] Несторовић 1972: 76.

41] Нав. gело: 36.

42] Истио: 77.

43] Јосимовић 1860: 63.

44] Roter-Blagojević 1998: 256.

45] Ђурић-Замоло 1980.

Зборник закона и уреgаба у Краљевини Србији изgайих оg 1. јану apa 1900. gо краја исйе їоgине (1903), Београд: Краљевско-српске државне штампарије.

Јосимовић, Е. (1860), Грађанска архииекииура и ірађење йуйова, Београд: У Књигопечатни Књажевства Србског.

Којић, Б. (1949), Стиара їраяска и сеоска архииекейура у Србији, Београд: Просвета.

Крстић, К. П. (1982), Архииеекиионске консиирукиије 2, Београд: Научна књига.

Lefevre, L. (1900), Architectural pottery, London: Scott, Greenwood and Co.

Маџаревић, Р. (1970), Реферай бр. 905/1 од 10. 7. 1970, Београд: Документација Завода за заштиту споменика културе града Београда.

Милутиновић, С. Д. (1894), Наука о іррађи, Београд: Државна штампарија Краљевине Србије.

Несторовић, Б. (1963), Капетан Мишино здање, Гоgищъак іраga Беоїраga IX-X (Београд): 81-98.

Несторовић, Б. (2006), Архийекйура Србије у ХІХ веку, Београд: Art Press.

Несторовић, Н. (1927), Грађевинске констирукиије : ручна књига за 
техничаре и грађевинаре, Београд: Државна штампарија Краљевине CXC.

Несторовић, Н. (1972), Грађевине и архииекиии у Беоїраgу йроилой сйолећа (поновљено издање из 1937), Београд: Институт за архитектуру и урбанизам Србије.

Павловић, С. Д. (1955), Конзерваторско-рестаураторски радови у Београду, Годишґак їраgа Беоїраgа II (Београд): 271-306.

Петровић, Д. и др. (ур) (1966), Класииизам коg Срба [књ. 2], Грађевинарстиво, Архивска грађа, предговор Коларић, М., Београд: Просвета.

Петровић, М. (1930), Беоїраg йре стио їоgина, Београд: Народна мисао.

Радовановић, М. (1974), Демоірафски оgноси 1815-1914, у: Историја Београда, књига 2: Деветнаести век, ур. Чубриловић, В., Београд: Српска академија наука и уметности, Одељење историјских наука : Просвета: 267-298.
Раш, Г. (2008), Свеииионик исииока, у: Београд у деветнаестом веку, ур. Ћоровић, Љ., Београд: Библиотека града Београда: 64-65.

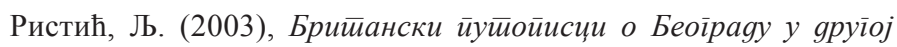
иоловини 19. века, у: Београд у делима европских путописаца, ур. Раденковић, Љ., Београд: Балканолошки институт САНУ: 221-237.

Ротер-Благојевић, М. (2006), Сйамбена архииеекйура Беоїраgа у 19. и йочетиком 20. века, Београд: Архитектонски факултет Универзитета у Београду : Орион арт.

Roter-Blagojević, M. (1998), Pojava prvih zakonskih propisa i standarda u oblasti građevinarstva u Srbiji tokom 19. i početkom 20. veka, Izgradnja 5 (Beograd): 245-258.

Стојановић, Д. (2009), Калярма и асфалй, Београд: Удружење за друштвену историју.

\section{Summary: LJILJANA ĐUKANOVIĆ}

\section{DEVELOPMENT OF CONSTRUCTION TECHNIQUES IN RESIDENTIAL ARCHITECTURE OF BELGRADE DURING THE 19th AND EARLY 20th CENTURIES}

The period before World War I has been marked with intense development of construction techniques and the introduction of new construction systems and materials. The new, brick-based building techniques, were to become traditional ways of building and to prevail in the construction of family houses throughout the 20th century. The then-established basic rules have been largely retained until today. The development of this system can be observed through the changes in wall thickness, mezzanines, and finishing techniques; however, general principles of brick masonry were to remain unchanged over the next hundred years. Apart from significant changes in construction techniques, in this period the foundations for national construction legislation were laid, and local industry of building materials was established, forming the basis for further development of construction industry.

\section{Illustrations}

Fig. 1 Development of construction techniques in the first half of the 19th century (Drawing: Lj. Đukanović)

Fig. 2 Lyceum of Dositej Obradović, the side facade with the arrangement of timber-framed elements (Institute for the Protection of Cultural Monuments, Belgrade)

Fig. 3 Lyceum of Dositej, detail of facade overhang documented for the 1962 restoration (Institute for the Protection of Cultural Monuments, Belgrade)

Fig. 4 Residence of Princess Ljubica, wooden mezzanine ceilings and facade, prior to the restoration (Institute for the Protection of Cultural Monuments, Belgrade)
Fig. 5 Residence of Princess Ljubica, cross-section (Institute for the Protection of Cultural Monuments, Belgrade)

Fig. 6 Captain Miša's Building, cross-section of the lobby and hall (Institute for the Protection of Cultural Monuments, Belgrade)

Fig. 7 Building of the New Military Academy, cast iron columns (Photograph: M. Roter Blagojević)

Fig. 8 Prussian vault (Photograph: M. Roter Blagojević, drawing P. Krstić 1982: 8)

Fig. 9 Expanded metal and the mesh making machine produced in 1900 (https://de.wikipedia.org/wiki/Streckmetall, accessed 30 March 2017) 